\title{
T empo e expectativa em música popular: duas obras, duas origens
}

\author{
Ataualba J. A. de Meirelles
}

\begin{abstract}
Resumo: O presente artigo aborda o processo composicional utilizado na cançáo Fé na Santa Sagrada Escritura, de Xangai (Eugênio Avelino) e Antônio Carlos M. Pinto, e na música instrumental Francamente \#2, de Ataualba Meirelles. A primeira, música regionalista vinda da cultura popular; a segunda, vinda do fusion, numa mistura do jazz com a música popular brasileira; ambas concebidas na segunda metade do século XX. A abordagem dá enfoque a expectativas decorrentes de irregularidades na métrica e nos padrôes de compasso. Apesar de ambas as composições apresentarem irregularidades temporais, as origens desses processos vêm de fontes distintas: uma da cultura popular, outra da academia. Iniciamos com uma explanação sobre a questão do tempo na música, para em seguida tecer uma análise abordando esse aspecto nas obras supracitadas.
\end{abstract}

Palavras-chave: tempo em música, expectativa em música, polimetria, .

\section{Time and expectation in popular music: two works, two origins}

Abstract: The present article deals with the compositional process used in the song Fé na Santa Sagrada Escritura, from Xangai (Eugênio Avelino) and Antônio Carlos M. Pinto, and in the instrumental music Francamente \# 2, by Ataualba Meirelles. the first, regionalist work coming from popular culture; the second, coming from fusion, in a mixture of jazz and Brazilian popular music; both conceived in the second half of the twentieth century. The approach focuses on expectations arising from irregularities in metrics and time signatures. Although both compositions present temporal irregularities, the origins of these processes come from different sources: one from popular culture, another from the academy. We begin with an explanation on the question of time in music, and then weave an analysis addressing this aspect in the works mentioned above.

Keywords: time in music, expectation in music, polymetry,

\section{Tiempo y expectativa en la música popular: dos obras, dos orígenes}

Resumen: Este artículo aborda el proceso compositivo utilizado en la canción Fé na Santa Sagrada, de Shanghai (Eugênio Avelino) y Antônio Carlos M. Pinto, y en la música instrumental Franamente \# 2, de Ataualba Meirelles. La primera, música regionalista de la cultura popular; el segundo, proveniente de la fusión, en una mezcla de jazz y música popular brasileńa; ambos concebidos en la segunda mitad del siglo XX. El enfoque se centra en las expectativas que surgen de las irregularidades en las métricas y las firmas de tiempo. Si bien ambas composiciones presentan irregularidades temporales, los orígenes de estos procesos provienen de distintas fuentes: una de la cultura popular, la otra de la academia. Comenzamos con una explicación sobre el tema del tiempo en la música, para luego tejer un análisis que aborda este aspecto en las obras mencionadas.

Palabras clave: tiempo en la música, expectativa en la música, polimetría, 


\section{Introduçáo $_{\text {Ans }}$}

A música popular com seus métodos predominantemente empíricos, surpreende a todo instante com ousadias inusitadas, nos brindando frequentemente com soluçóes musicais por demais fluentes e "orgânicas". Quando saímos da seara da "música comercial", encontramos nichos específicos em meio à música regional, ao rock progressivo, à música instrumental e ao fusion, dentre outros, que nos trazem admiráveis experimentaçóes no campo da métrica e nos padróes de compasso. Tais irregularidades ora no trato do tempo, alturas ou em outros aspectos da composição, geralmente são típicas de uma cultura própria, seja do estilo específico da obra ou de caráter antropológico e social. Devemos ser cuidadosos ao "formatar" para análise, algumas obras de estilos populares como a música regionalista por exemplo. Ao grafá-las, trazendo-as para o universo da música teórica, nossas ferramentas podem ser pouco apropriadas para esse fim. Veja o que diz Margareth Milani:

O compositor Ernst Widmer chama a atenção para o fato de que práticas modais populares quando grafadas perdem parte de sua originalidade, quando as impurezas de alturas são "corrigidas", assim como possíveis oscilaçôes ou irregularidades métricas. (MILANI, 2008, p.106)

Muitas vezes, grafar os pulsos e divisóes métricas de algumas obras regionalistas é tarefa de fato complexa. Alguns autores sugerem que o tempo é o elemento mais importante em música, e enquanto outros tipos de arte se manifestam no espaço, a música é a arte no tempo (LANGER, 1980). Susanne Langer diz ainda que o tempo é o componente mais significativo da música e o meio de comunicaçáo dessa arte com o espírito humano.

O tempo musical - diferente do tempo medido - depende unicamente do fator cognitivo; por isso a importância de seu estudo e do entendimento de como os compositores o manipulam. A audiçấo de uma obra pode nos fazer perceber o tempo de forma diferente do "tempo do relógio". Kramer (1988) define a percepção do tempo musical como linear ou não-linear . O tempo linear, segundo Kramer, é aquele onde o fluxo musical é direcional e progressivo, fruto de causalidade, isso é, depende de um fator inicial enquanto torna-se a causa do que está por vir. Já o tempo não-linear, é aquele onde o fluxo musical segue uma regra estática que avança por toda a obra ou segmento musical de forma pouco gestual, sem mudanças significativas ou dependências de eventos anteriores. Veja o que diz Kramer:

Vamos identificar a linearidade como a determinação de algumas características da música de acordo com as implicaçóes que surgem de eventos anteriores da peça. Assim, a linearidade é processiva. Náo-linearidade, por outro lado, é não-processiva. É a determinação de algumas características da música de acordo com as implicações que surgem dos princípios ou tendências que regem toda uma peça ou seção. Vamos também definir o tempo linear como o continuum temporal criado por uma sucessão de eventos em que eventos anteriores implicam posteriores e posteriores são consequências dos anteriores. Tempo não-linear é o contínuo temporal que resulta dos princípios que governam permanentemente uma seçáo ou peça. (KRAMER, 1988, p. 20)

Definiçôes reiteradas por Amaro (2015) de forma ainda mais clara, veja em seguida:

No tempo linear os materiais musicais guardam uma intensa relação de cau- 
salidade, de modo que o fluxo musical pode ser entendido como um processo direcional e evolutivo de uma ideia inicial. Essa perspectiva guarda fortes relaçóes com a criação de expectativa, dialogando, portanto, com a tradição da música tonal. Mais que isso, o tempo linear se aproxima do pensamento predominante da cultura ocidental que concebe o tempo, de uma maneira geral, nas relaçóes entre o binômio passado e futuro, [...] Enquanto o princípio da linearidade está no fluxo constante, uma situação de não-linearidade tende a não se desenvolver, a não mudar. No tempo náo-linear os eventos musicais não guardam relaçóes causais, manifestam-se como resultado de princípios pré-estabelecidos que governam uma obra ou determinado trecho dela. (AMARO, 2015, p. 23, 24)

Processos compositivos baseados no tratamento clássico do sistema tonal que operam através de seu ciclo de quintas e consequentes progressóes harmônicas, são representantes claros do tempo linear; o que nos leva a deduzir que a natureza temporal de uma obra náo deve ser definida apenas pelo pulso, métrica ou ritmo, mas pela conjunção dos aspectos musicais. Muito embora o aspecto temporal seja, sem dúvida, um dos mais importantes nesse contexto.

A música popular, em sua maioria construída num ambiente tonal/modal, é sem dúvida, inclinada a um discurso linear; enquanto a música de tradição oral, ao contrário, habitualmente é cíclica. Em meio à música popular, quando a irregularidade do pulso e da métrica dos compassos nos chamam a atenção, esses, como elementos que geram 'surpresa' , podem confirmar o caráter linear da composição, desde que tais 'surpresas' se apresentem num contexto progressivo. Veja o que Kramer diz a esse respeito:

Surpresas - eventos que são realmente inesperados e não preparados - existem na música tonal, no entanto. A surpresaéfrequentemente um produto do pensamento linear. Por um evento ser inesperado sugere-se que implicaçôes foram estabelecidas.

(KRAMER, 1988, p.29)

Alguns compositores 'populares' tratam o tempo de forma complexa, alternando padróes de acentos ou utilizando superposição de diferentes métricas. Não nos referimos simplesmente a compassos alternados, mas a variaçóes complexas na métrica, criando uma expectativa imprevisível para o ouvinte. $\mathrm{O}$ nível de dificuldade na escuta de um padrão rítmico pode ser avaliado pela previsão de um pulso periódico (RAMOS, ELIAS, 2013). No caso da imprevisibilidade, há uma expectativa pelo desconhecido, gerando interesse na audição.

\section{Música Popular e complexidade}

Há indícios que a partir de meados do Século XX, a música popular urbana venha sendo suprida cada vez mais por compositores com experiência acadêmica, com um olhar repleto de práticas próprias da música de concerto contemporânea. Com uma visão estrutural mais ampla, certamente passaram a elaborar seus projetos composicionais num ambiente mais "cartesiano" que o costumeiramente utilizado na música popular. Há uma grande chance desse processo ter gerado inúmeras obras notadamente muito cerebrais, afastando-se em essência desse tipo de música. Em contrapartida, alguns desses compositores - de certeza com mais vivência na esfera da música popular - lograram grandes êxitos na criação de obras com estruturas lógicas mais complexas - "pero sin perder la ternura jamais" 
-, preservando a essência, a fluidez e organicismo típicos da música popular.

De outra forma, alguns compositores de estilo regionalista, com pouco ou nenhum conhecimento acadêmico sobre música, praticam desde sempre as mesmas irregularidades temporais em suas composiçóes, baseados quase somente na vivência diária da sua própria cultura popular.

Nossa pesquisa trata de dois exemplos contrastantes quanto a suas origens, mas convergentes quanto a seus resultados; um vindo da cultura popular, outro da música urbana.

\section{Fé na Santa Sagrada Escritura}

X angai (Eugênio Avelino), nascido em 1948 na cidade de Itapebi, no sul da Bahia, faz parte de um grupo seleto de "regionalistas" de onde podemos citar Elomar (Elomar Figueira de Mello) eVital Farias, dentre outros. Estes, com suas "cantorias" mantêm viva a cultura do trovador medieval, aquele que trazia notícias verídicas ou "floreadas" de outras paragens através de seus versos, na Europa do século XIII. O Brasil, com sua vasta extensão territorial, sempre abrigou em seu interior uma grande quantidade de culturas regionais diferenciadas em redutos isolados, onde até há algumas décadas rareavam notícias e hábitos vindos das grandes cidades. Isso veio a promover nessas regióes, o desenvolvimento de uma cultura própria, sólida e peculiar, sem a intervenção de maneirismos alheios.

Féna Santa Sagrada Escritura, de Xangai e Antonio Carlos M. Pinto, na interpretaçáo e concepção de Xangai, ganha uma 'cor' particularmente original e rica em signos trovadorescos, numa narração poético/musical muito apropriada à descrição do tema a que se propóe.

Os versos dessa obra tratam da "peleja" de um peregrino religioso no sertáo nordestino, vivendo de forma dura e pregando de porta em porta. A poética revela a tensão da vida de peregrino, para em seguida vir com o alívio trazido por ele às "almas necessitadas". Essa direcionalidade (tensão/relaxamento) pode ser subliminarmente percebida no refrão como esclareceremos mais à frente.

A parte A da composição apresenta uma melodia com irregularidades métricas, denunciadas pelos acentos assimétricos, certamente sugeridos pelos versos metricamente desproporcionais. Isso vem acarretar, inevitavelmente, descontinuidade nos padróes de compasso como mostra a Figura 1:

Figura 1: Refrão de Fé na Santa Sagrada Escritura

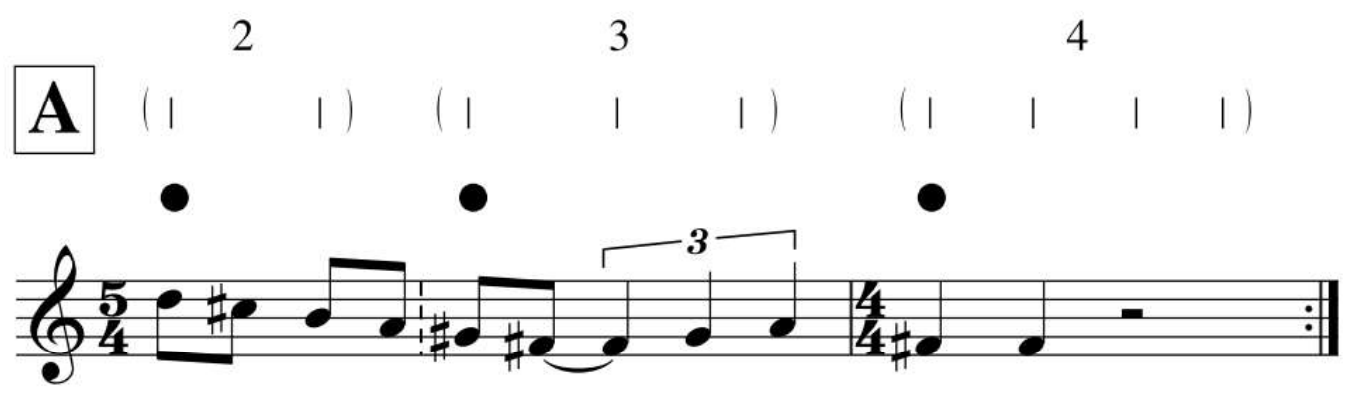

Fé na San-ta Sa-gra - da es-cri - tu - ra 
O verso "Fé na Santa Sagrada Escritura" cabe perfeitamente num compasso alternado 5/4 (2+3), para em seguida, apresentar um 4/4 com metade do compasso em pausa. Todo o refráo poderia ter sido construído em $4 / 4$ caso o compositor assim o quisesse, mas Xangai optou - provavelmente de forma intuitiva - por seguir os acentos métricos do início do verso, "Fé na Santa Sagrada escri..."; criando, a partir desses acentos naturais, um grouping(KRAMER, 1988), escrito em 5/4 (2+3). Essa utilizaçáo dos acentos baseados na métrica dos versos, confere à obra sua característica mais notável. A ordem dos compassos, $5 / 4(2+3)$ e $4 / 4$, no refraáo, promove uma desaceleração da métrica $(2+3+4)$ (figura 1$)$, onde o início "Fé na Santa..." se dá no grupo de 2 pulsos (2/4), mais rápido e tenso; "Sagrada Escri..." no grupo de 3 pulsos (3/4), com tensão mediana; e "...tura" + silêncio no grupo de 4 pulsos (4/4), com afrouxamento da tensão. Isso pode ser notado também, na ampliação da duraçáo das notas de cada trecho. $\mathrm{O}$ início (grupo de 2 pulsos) com colcheias; o trecho intermediário (grupo de 3 pulsos) com quiálteras de semínimas; e finalmente (grupo de 4 pulsos) com semínimas simples seguidas de pausa; portanto há aqui também uma desaceleração de durações. Após a inquietação inicial da vida de peregrino, o relaxamento trazido por ele aos "fiéis": Uma meta composicional.

No refrão da obra em estudo há certa ousadia por parte do compositor ao apresentar a manipulaçáo do tempo de uma forma táo atípica, já que a grande maioria das cançôes apresenta seus refróes livres de irregularidades que possam vir a perturbar a compreensibilidade dos mesmos, tornando-se a zona onde o ouvinte ancora sua memória emocional. No caso em estudo, o tratamento rítmico e de duraçóes baseados na métrica dos versos é táo bem estruturado que soa espontâneo e orgânico, tornando o trecho marcante e de fácil assimilação como se apresentam habitualmente os refróes.

$\mathrm{O}$ restante da parte $\mathrm{A}$, se mostra igualmente irregular com relaçáo à métrica, como mostra a figura 2 :

Figura 2: Parte A de Fé na Santa Sagrada Escritura

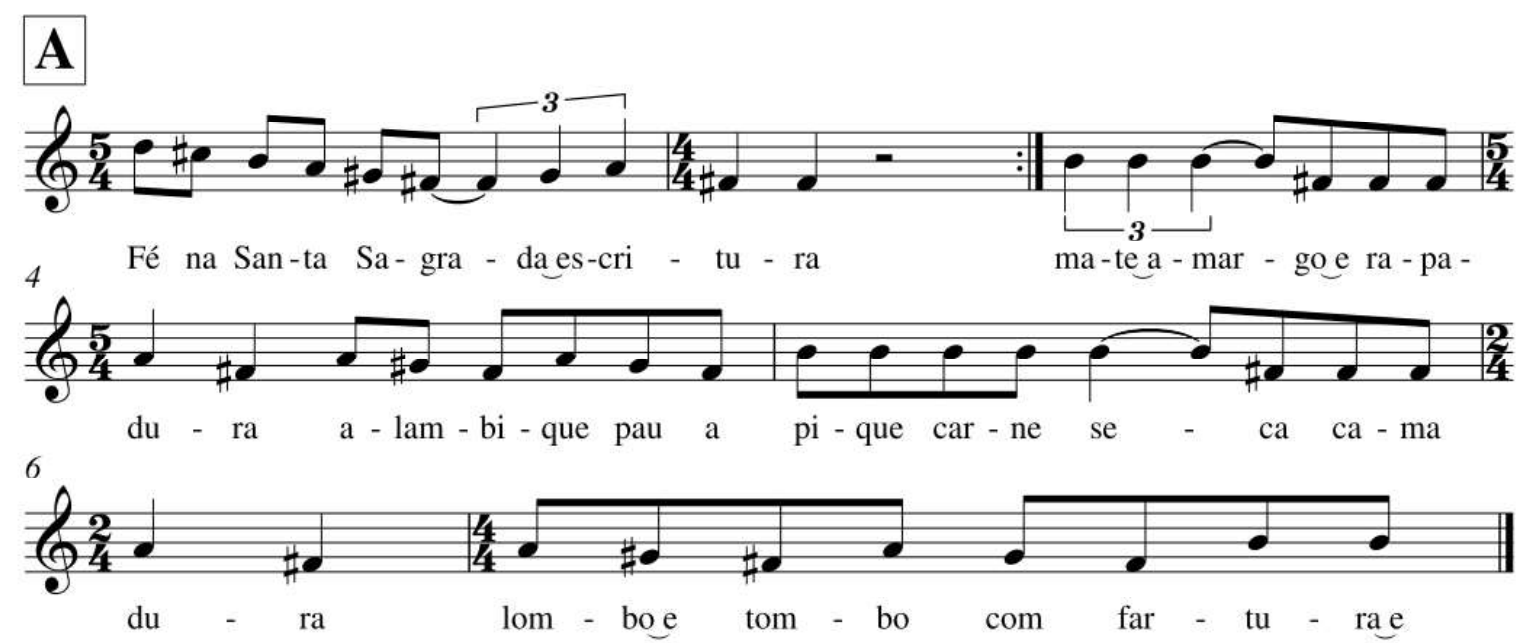

Nesse trecho - iniciado com o refrão - a métrica irregular estimula uma audição atenta e alerta. Apesar de se encontrar em meio a padróes de compasso bem variados, a melodia segue de forma fluente e orgânica. Aqui, a irregularidade rítmica motivada pela métrica dos versos é que traz mérito ao trecho gerando especial expectativa na audição, pois o contorno melódico e a progressão harmônica do segmento após o refrão, são repetitivos 
e monótonos. Neste trecho (após o refrão) a harmonia apresenta uma sucessão cíclica dos acordes de Si menor e Fá sustenido menor, enfatizando por repetição as notas Si e Fá sustenido, fundamentais dos acordes. Esse aspecto simplista facilita sobremaneira a absorção da métrica irregular, já que não concorre em complexidade com a mesma.

Quanto maior a incerteza do ouvinte a respeito da direcionalidade na audiçáo de uma obra, maior a tensão na escuta. Essa incerteza pode se dar pela ignorância do ouvinte com relaçáo àquele tipo específico de música, aquela cultura ou estilo artístico, ou mesmo como uma reação emocional ao já conhecido (RAMOS, ELIAS, 2013). Nesse contexto a irregularidade nos padróes de compasso geralmente nos direciona a algum nível de tensão por náo ser uma prática corriqueira em nossa cultura ocidental tonal. Entre os compositores ocidentais, a tensão e seu relaxamento têm sido os elementos mais utilizados na manutenção da escuta.

As metas composicionais no tonalismo têm se baseado principalmente na construção de tensóes, para em seguida solucioná-las. Isso está presente em toda a história da arte ocidental, particularmente nas artes temporais. Se no tonalismo isso fica patente principalmente no uso de progressóes harmônicas, no pós-tonalismo isso se dá através da manipulação de vários outros aspectos, dentre eles, a irregularidade rítmica . Esse direcionamento cria uma expectativa que estimula a percepçáo de um tempo linear na audição.

Por outro lado, graus elevados de familiaridade podem gerar baixo nível de complexidade na escuta, acarretando perda de interesse na audição caso isso transcorra por um longo período de tempo (RAMOS, ELIAS, 2013). Essa expectativa gerada pela familiaridade conduz o ouvinte à percepção de um tempo não-linear. Em nossa música ocidental, é corrente a criação de estruturas composicionais com segmentos mais lineares e outros menos lineares, resultando num desejável equilíbrio de expectativas.

$\mathrm{Na}$ obra analisada, a parte $\mathrm{B}$, ao contrário da $\mathrm{A}$, apresenta um padrão de compassos estável em 4/4, criando uma atmosfera de relaxamento auditivo, dessa vez com a expectativa de um fluxo contínuo e sem surpresas, a tempo, sugerido num verso dessa passagem: "canto aliviador". Veja a figura 3.

Figura 3: Parte B de Fé na Santa Sagrada Escritura

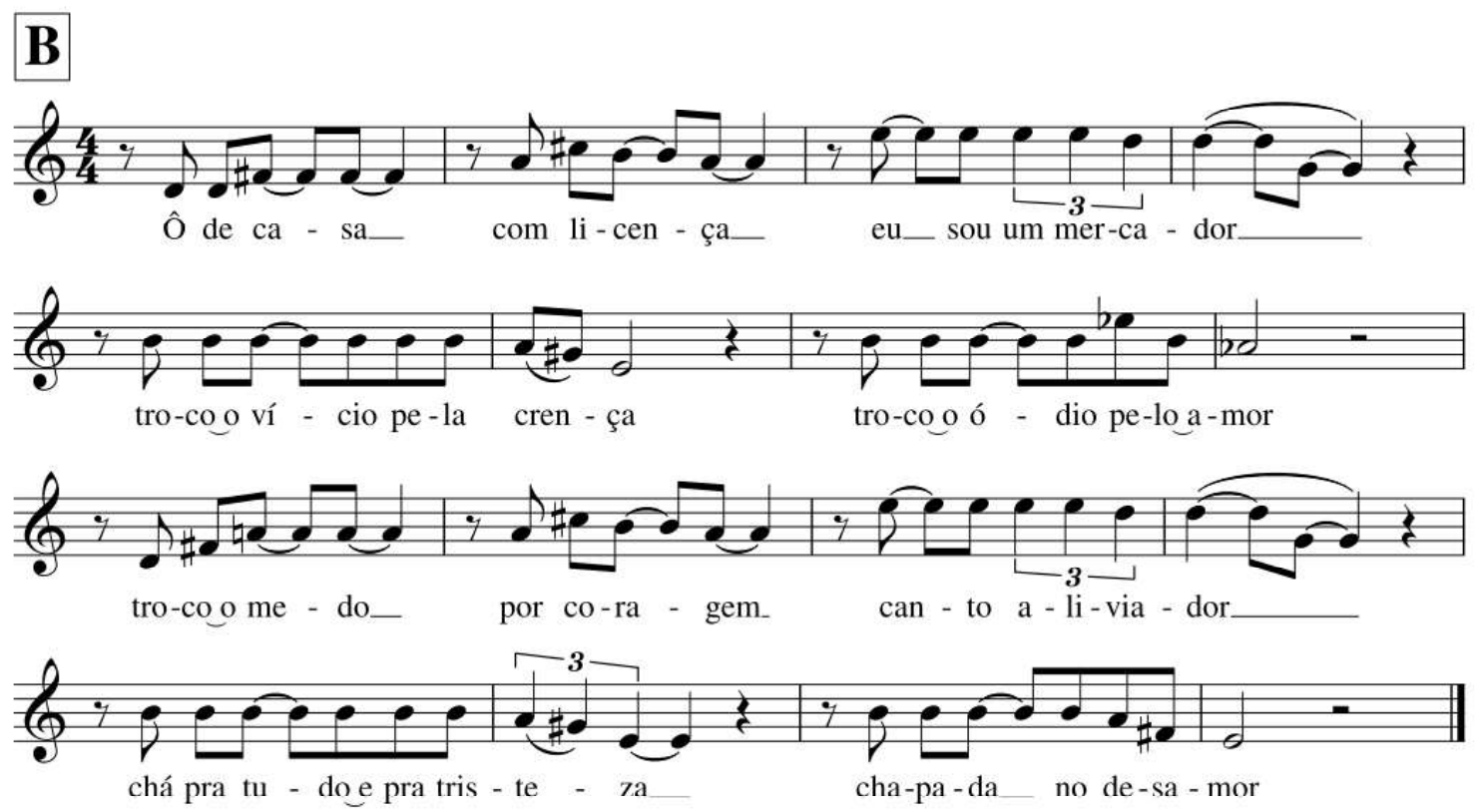


Enquanto os versos da parte A tratam do martírio do peregrino, os versos da B tratam do alívio às dores dos "mortais", como podem ver na figura 3. É importante frisar que sempre há expectativa. Mesmo no caso da parte B como um trecho estável ritmicamente, o esperado é que não haja alteraçóes rítmicas bruscas, portanto, uma expectativa.

O tipo de expectativa criada na parte $\mathrm{B}$ resulta numa percepçáo mais própria a um tempo náo-linear, revelando uma abordagem mais conservadora e sem sobressaltos, por isso propensa à estabilidade e moderação. Nesse caso, o aspecto rítmico é um poderoso gerador de expectativas em música. Referências baseadas no tempo podem criar facilmente tensão e relaxamento, gerando ansiedade ou descanso na perspectiva dos eventos futuros daquela audição. São expectativas que podem abreviar ou dilatar a percepção do tempo, fixar a atenção ou criar dispersão durante a apreciaçáo de uma obra. Veja o que dizem Ramos e Elias:

[...] os seres humanos estabelecem referências temporais com o intuito de fixar processos de atenção. Tais referências atuam na mediação entre a atenção analítica (consciência de detalhes locais) e a atenção para eventos futuros (consciência de processos globais e metas). A interação existente entre este pulso interno e eventos regulares externos (ambiente) define o processamento de características dos estímulos percebidos. (RAMOS, ELIAS, 2013, P. 91)

Como vimos, a parte A da composição expressa tensão e martírio, enquanto a seguinte, $\mathrm{B}$, relaxamento e alívio. Essa meta composicional (tensão > relaxamento) é também sintetizada no refrão como um microcosmo da obra. Veja a figura 4.

Figura 4: Metas de Fé na Santa Sagrada Escritura

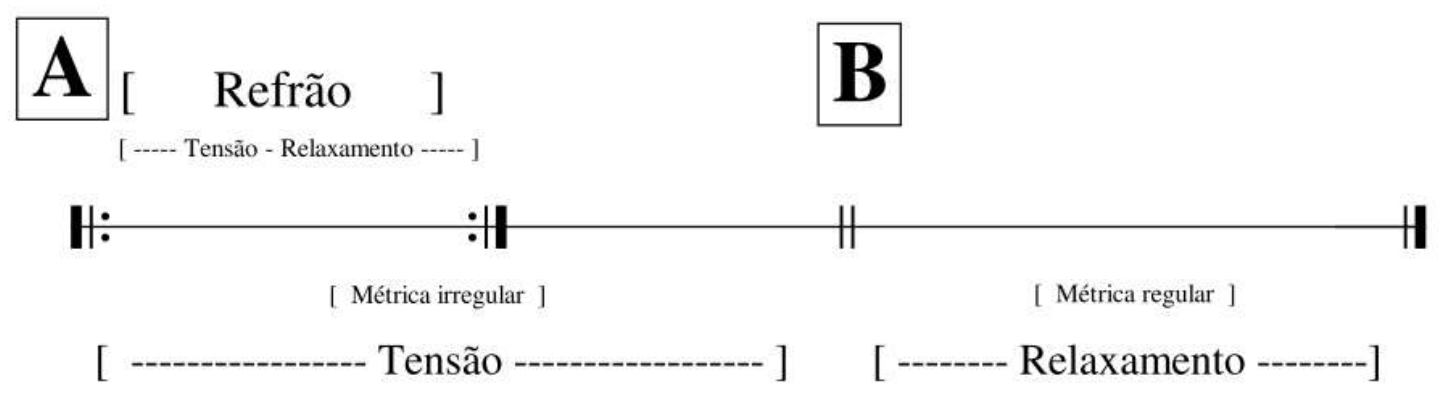

A métrica irregular propicia a noção de tempo linear por criar mais facilmente, condições que favorecem a direcionalidade. Desde que não seja utilizada de forma abusiva e repetitiva, facilita a criação de gestos direcionados a metas composicionais.

\section{Francamente \#2}

Por outro lado, um exemplo tirado do meu próprio trabalho como compositor pode ilustrar um outro viés da manipulação do tempo em música popular, dessa vez com suas bases vindas da academia, e não da cultura popular.

Nasci em Salvador, na Bahia, e desde meados dos anos 1970 travo contato com o jazz e a MPB, compondo, arranjando e acompanhando artistas, como baixista. No início da década de 1980 ingressei no curso de Composição e Regência da UFBA, me deparando com um novo universo no tratamento compositivo. Estudei com três geraçóes de professo- 
res, dentre eles Ernst Widmer, Lindembergue Cardoso, Fernando Cerqueira, Paulo Costa Lima, Agnaldo Ribeiro e Wellington Gomes. Imediatamente reuni os novos conhecimentos em composiçáo, à minha experiência com música instrumental vinda do jazz, agregando processos compositivos próprios da música contemporânea de concerto, à música popular. Dentre eles, o serialismo e manipulaçóes do tempo como irregularidades métricas e superposição de compassos. Pois sob o ponto de vista da manipulaçáo do tempo, analisaremos aqui a música instrumental Francamente \#2, de minha autoria.

$\mathrm{Na}$ obra em análise, a linha do baixo é o centro de toda a estrutura composicional. Baseada numa série, estabelece centricidade em Lá e Sol, por repetiçáo. Veja a figura 5:

Figura 5: Linha do baixo em Francamente \#2

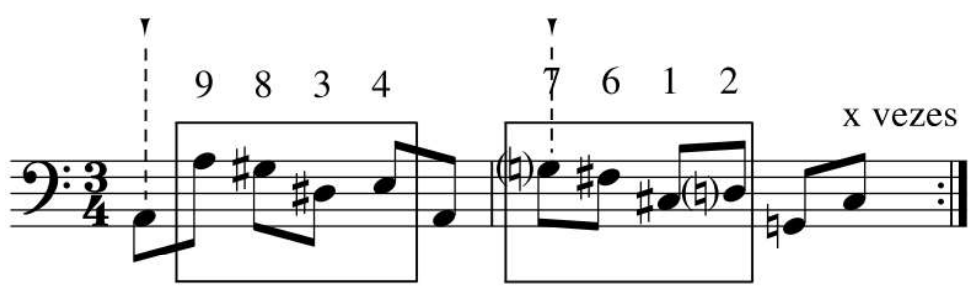

O segmento ordenado $(9,8,3,4)$ encontrado no primeiro compasso, é repetido transposto 1 tom abaixo no segundo $(7,6,1,2)$, mas deslocado ritmicamente em sua posição no compasso, mantendo o mesmo contorno como mostra a figura 5. Esse deslocamento fraseológico executado de forma cíclica, acaba originando um Grouping "vivo" ritmicamente e gerando um groove singular que se ressalta quando executado em conjunto com com a bateria como veremos logo a seguir.

Apesar da parte A da composiçáo ser ternária, utiliza um padrão rítmico de natureza quaternária na bateria, muito utilizado no estilo fusion. Veja como seria esse padrão em 4/4 caso o trecho fosse quaternário:

Figura 6: Padrão rítmico quaternário

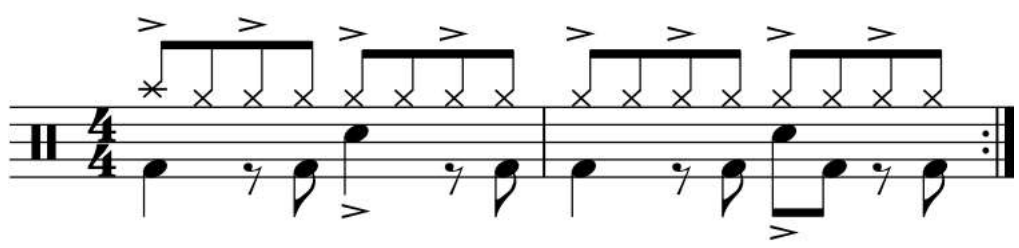

Contudo a música em análise, por ser ternária, não poderia empregar o padrão visto na figura 6 assim como está escrito, então o utiliza de forma encurtada: um 3/4 sugerindo o padrão visto na figura acima, em 4/4, mas incompleto. Veja a figura 7 :

Figura 7: Padrão rítmico ternário baseado no quaternário

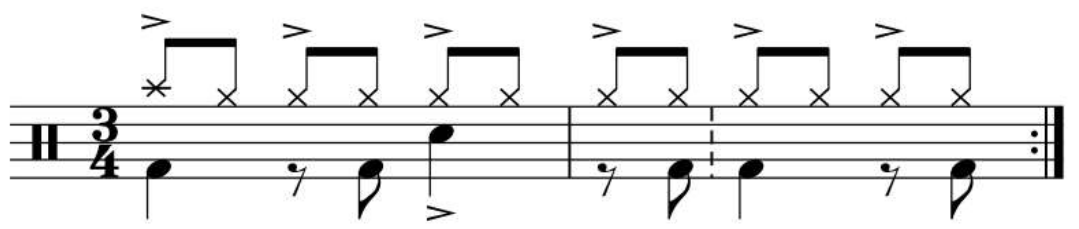


Se atentarmos para o primeiro compasso do padrão quaternário da bateria (figura 6) veremos que ele se encontra por inteiro no padrão ternário da música, extrapolando o compasso $3 / 4$, como mostra a linha pontilhada da figura 7 , mais a metade do mesmo em seguida, tornando-se um novo padrão com acentos deslocados em relação ao tempo forte do compasso. Esse desencontro de acentos entre o compasso ternário e a bateria quaternária, gera um groove singular como mostra a figura 8:

Figura 8: Baixo e Bateria - parte A de Francamente \#2

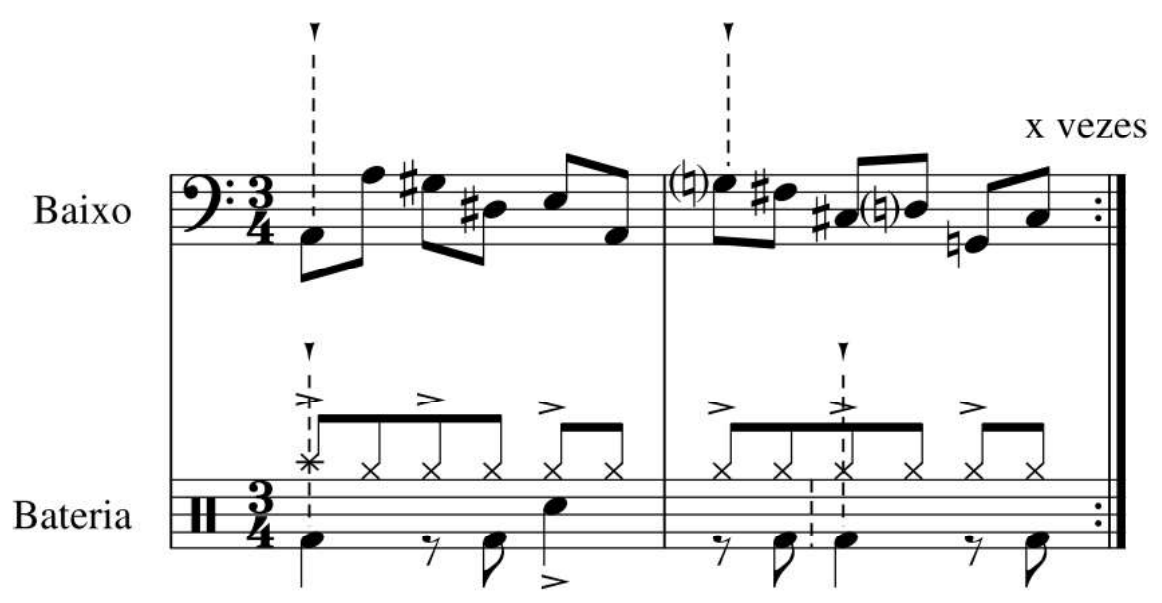

Essa polimetria ou superposição de acentos métricos (MOREIRA, 2008), também será encontrada em outro momento da mesma composição. Num pequeno trecho da parte A da música, em 3/4, surge uma célula rítmica típica do ijexá, executada por um agogô, em 2/4, como mostram as linhas pontilhadas na figura 9 a seguir:

Figura 9: Superposição de compassos em Francamente \#2
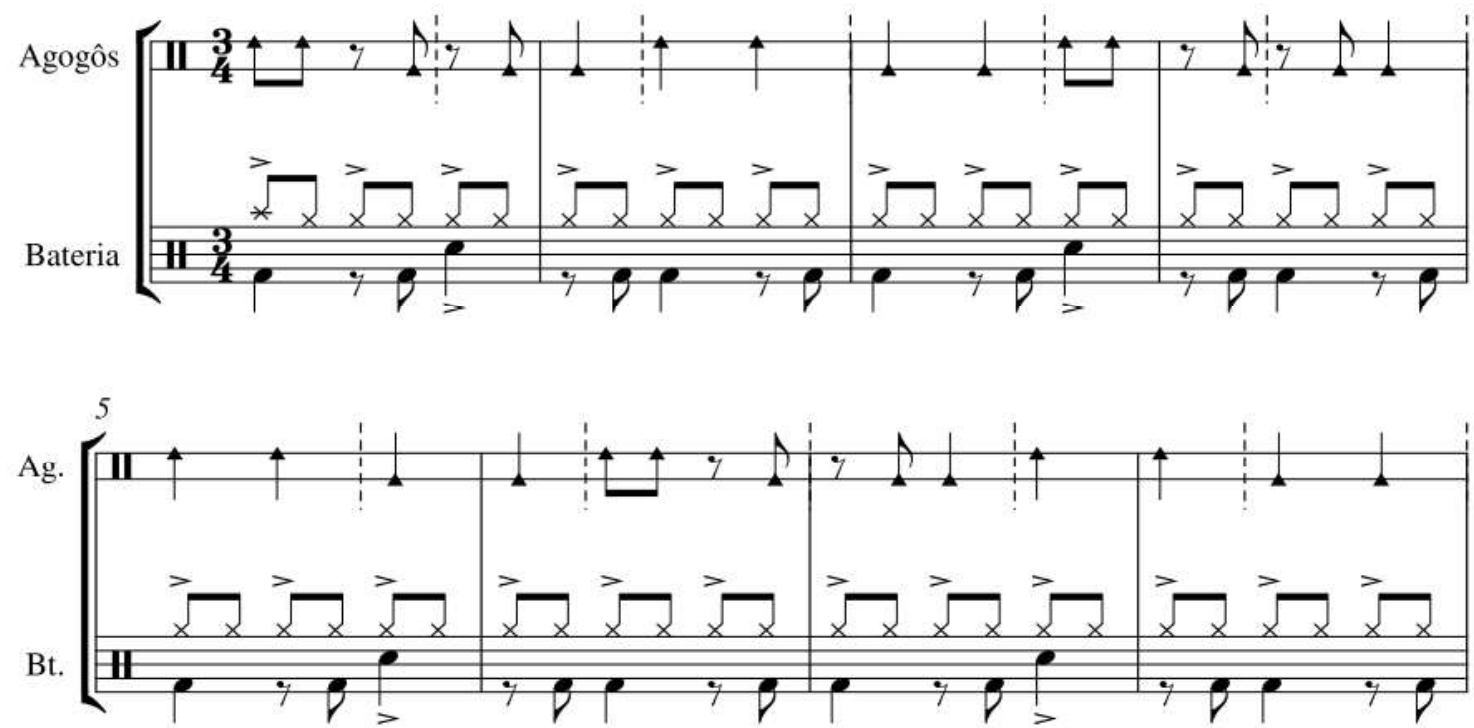
Tal polimetria, simultânea a outra superposição de compassos entre as linhas do baixo e da bateria - citada mais acima -, gera um groove momentâneo repleto de expectativas. Aqui há acentos em 4 níveis: acento do compasso 3/4, acento da bateria executando o padrão quaternário, acento do deslocamento do segmento melódico do baixo, e acento em 2/4 proveniente do ijexá executado pelo agogô. Veja a figura 10.

Figura 10: Superposição de acentos em Francamente \#2

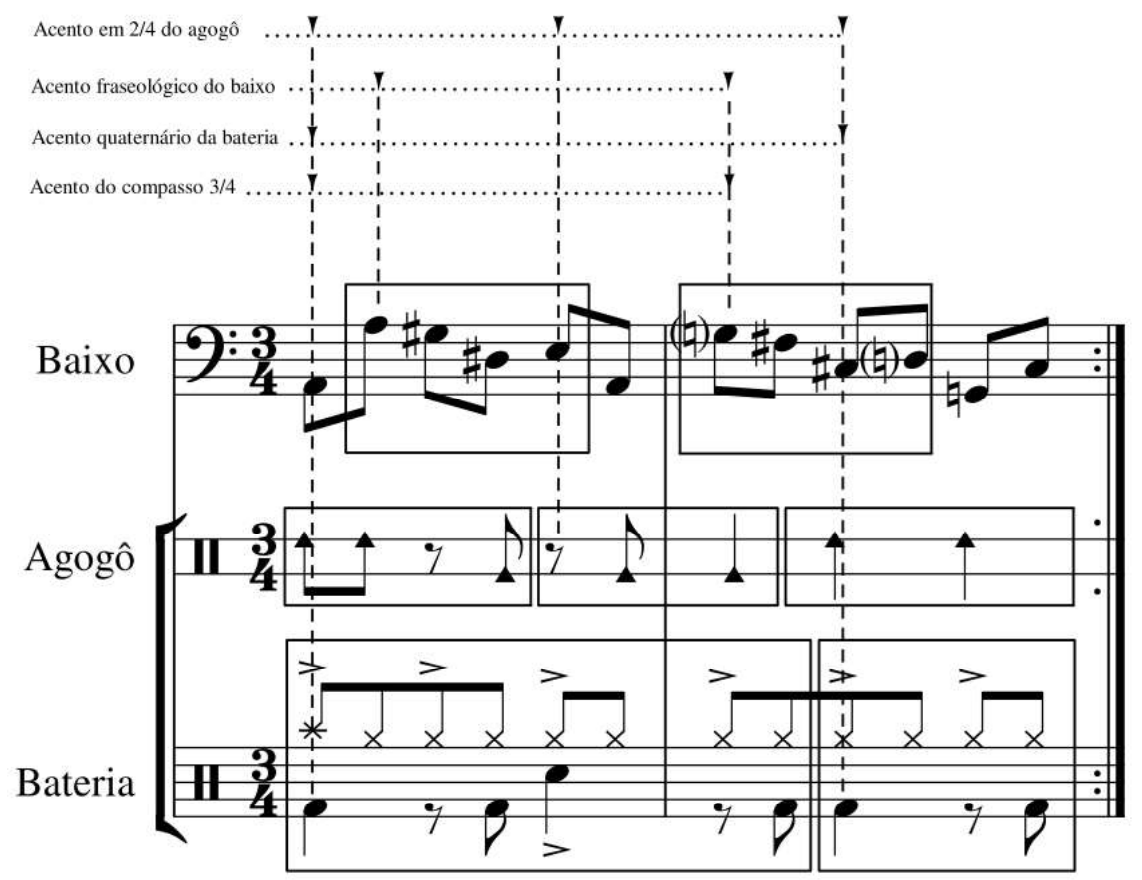

Por fim, outro aspecto sobre a manipulação do tempo nessa obra está na dubiedade entre o uso dos compassos 3/4 e 6/8, que ficam patentes em toda a composição. Enquanto a parte $\mathrm{A}$ está em $3 / 4$, a parte B está em $6 / 8$, mas a unidade de tempo do 6/8 (semínima pontuada) náo se encontrará no mesmo andamento da unidade de tempo do $3 / 4$ (semínima simples), mas sim, a semínima do primeiro será igual à semínima do segundo (semínima = semínima), ou seja, a unidade de tempo da primeira será igual a 2 terços da segunda. Isso cria a sensaçáo auditiva de que tudo continua em 3/4, no mesmo andamento, numa linha tênue que mantêm a dúvida no ouvinte. Veja a figura 11 .

A escuta da música analisada mantém o ouvinte sempre hesitante na percepçáo do compasso, do início ao fim. A natureza ternária da parte $\mathrm{A}$ fica atenuada pelo padrão quaternário da bateria, enquanto a natureza binária da parte $\mathrm{B}$ em $6 / 8$, fica comprometida pelo compasso ternário que o antecede e parece seguir em frente atravessando o trecho.

O conjunto de recursos relativos à manipulação do tempo, empregados na composição, a tornam um exemplo interessante de obra "popular", rica em expectativas. 
Figura 11: Estrutura de Francamente \#2

\section{Francamente \#2}
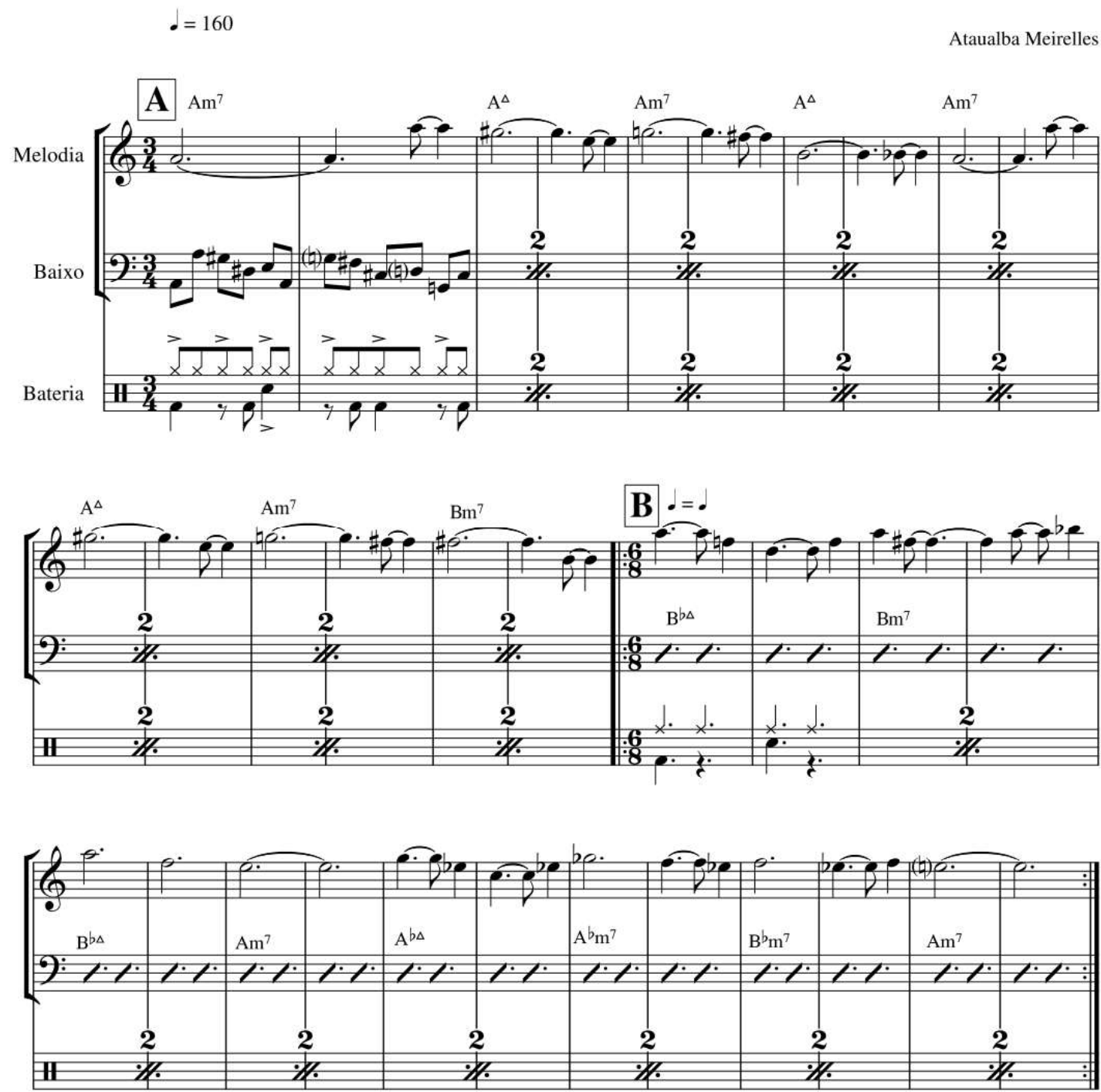

\section{Conclusão}

F'é na Santa Sagrada Escritura e Francamente \#2, são exemplos de composiçóes "populares” concebidas no século XX, que contemplam irregularidades temporais, contudo mantendo a fluidez e espontaneidade típicas da música popular; ainda que a segunda utilize recursos de planejamento estrutural de forma "consciente", típicos da academia.

Fé na Santa Sagrada Escritura é um bom exemplo de estrutura composicional baseado nas expectativas da dimensão temporal. $\mathrm{O}$ padrão irregular de compassos da primeira parte da música, apoiado nos acentos métricos dos versos, soa de forma equilibrada e fluente, apresentando direcionalidade e linearidade.

O fato de ser uma obra possivelmente construída de forma intuitiva, só a valoriza pois os meios intuitivos nada mais são que a consolidação da experiência empírica ao utilizar o arcabouço de vivências do compositor no meio cultural que habita. Essa forma de 
concepção utiliza um outro tipo de inteligência, desligada das amarras da lógica cartesiana.

Por outro viés, Francamente \#2 atinge as mesmas metas baseadas na manipulação do aspecto temporal, gerando expectativas e direcionalidade, mas dessa vez utilizando práticas vindas do meio acadêmico de forma "consciente", como particularmente a polimetria, criando um groove singular. É indiscutível a presença aqui de algum nível de material intuitivo que é próprio da música popular, o que mantém sua organicidade, contudo essa confluência entre o intuitivo e o "metódico" é que a torna uma obra original.

Podemos notar que ambas as composiçóes têm lógica e estrutura bem concebidas, mas enquanto a primeira segue o fluxo apontado pela métrica do verso de forma intuitiva, a última apresenta um pensamento compositivo mais calculado. Ambas, com características predominantemente lineares, são ricas em expectativas, originadas sobretudo pela manipulação do aspecto temporal.

\section{Referências}

AMARO, V. B. O ritmo como um articulador de gestos e processos composicionais na perspectiva de um diálogo com a capoeira. 2015. 179 f. Dissertação de Mestrado - Universidade Federal da Bahia, Salvador, 2015.

GROUT, D. J.; PALISCA, C. V.. História da Música Ocidental. Lisboa: Gradiva Publicações, S.A., 2014.

KRAMER, J. The Time of Music. New York: Schirmer Books, 1988.

LANGER, S. K. K. Sentimento e Forma: uma Teoria da Arte desenvolvida a partir de "Filosofia em nova chave". São Paulo: Perspectiva, 1980.

MEIRELLES, A. Trégua do Absurdo. CD BS008. Salvador: Pelourinho Discos, 2005.

MEYER, L.; COOPER G.. The Rhythmic Structure of Music. Chicago: The University of Chicago Press, 1956.

MILANI, M. Prelúdios tropicais de Guerra-Peixe: uma análise estrutural e sua projeção na concepção interpretativa da obra. 133 f. Dissertação - Universidade Federal da Bahia, Salvador, 2008.

MOREIRA, A. L. C. Olivier Messiaen - Inter-relação entre conjuntos, textura, rítmica e movimento em peças para piano. $498 \mathrm{f}$. Tese - Universidade Estadual de Campinas, Campinas, 2008.

RAMOS, D., \& ELIAS, A. A incessante espera pelo futuro: uma introdução sobre expectativas geradas pela dimensão rítmica em música. Percepta, v. 1, n. 1, p. 83-94, 2013.

XANGAI. Eugenio Avelino (Xangai). LP 599.404.558. Salvador: Estúdio de Invenções Ltda, 1990. 